\title{
Article
}

\section{Emmanuelle Lemaire* The Fear of Future Illness: An Analytical Comparison of English and French Law}

DOI 10.1515/jet-2016-0004

\begin{abstract}
The occurrence of multiple health-related catastrophes in the last 30 years has left a long-lasting imprint in people's minds, resulting in the public becoming more aware of the risks surrounding them. As a consequence, a rise in claims relating to the fear of contracting a future disease has mirrored the public's concern for their health in different EU Member States. In this paper, the author compares the judicial treatment of claims for fear of future illness in English and French Law and concludes that neither of the approaches is satisfactory to protect the interests of the parties involved. French courts have shown a flexible approach, stretching the functions of tort law to its limits, while English courts have taken an extremely rigid position on these claims, reducing the ambit of tort law to almost nothing. To reach this conclusion, the author analyses the key cases in both legal systems. Based on this analysis, the author then tries to find a compromise approach, setting out a basic framework which could limit legal uncertainty while protecting the interests of both claimants and defendants.
\end{abstract}

\section{Introduction}

The development of new technologies produces improvement in quality of life but can also produce risks for health. A new drug which aims to cure one illness can create the risk of causing another. The possibility of people being exposed to such risks may create an anxiety of future illness. This has been aggravated by past health-related catastrophes. ${ }^{1}$ This fear of future consequences may be explained by internal and/or external factors amongst which are an individual's

1 Such as the Thalidomide (Contergan) catastrophe for instance.

*Corresponding author: Emmanuelle Lemaire, PhD student, Research and Teaching Assistant (ATER), University of Paris II Panthéon-Assas, France, E-Mail: emma_94380@hotmail.fr 
particular vulnerability to stress ${ }^{2}$ and the (often distorted) image conveyed by the media. ${ }^{3}$

Fear and anxiety are unpleasant feelings created by the perception of threat whether it be an immediate threat (fear) or a future expected threat (anxiety). They are subjective in nature even though some situations will create the same reaction in most people. ${ }^{4}$ These feelings are usually considered a part of everyday life and no question of compensation generally arises. However in cases where anxiety has been caused by the wrongdoing of another, the question of liability could be raised. As such the following issues need to be addressed: first, can anxiety give rise to a cause of action in the legal systems studied, and if so, under which conditions? Second, in these legal systems, is the legal treatment of anxiety satisfactory, and if not, how could it be improved?

Although anxiety is a feeling that may arise in diverse situations, this article will attempt to answer the aforementioned questions in relation to a specific type of anxiety, namely, the fear of future illness. This particular anxiety is linked to the negative perception of a health risk, whether this risk is known or simply suspected. ${ }^{5}$ These are usually found in cases of occupational disease, medical negligence, defective products and sometimes private nuisance. This article will focus on the English and French legal systems. These two legal systems have been chosen due to their contrasting view on the legal treatment of the fear of future illness. It will be shown that the English legal system is very stringent, making it extremely difficult for claimants to recover damages for their fear of future illness. In contrast, the French legal system could be said to be too lenient, making it too easy for claims of anxiety to be successful. The aim of this paper is to demonstrate that both legal systems are too extreme in their positions and to investigate whether a middle ground is achievable in order to balance the interest of claimants and defendants.

This article is divided into four sections. The first provides an overview of the legal treatment of the fear of future illness in English law. The analysis will

2 A particular vulnerability to anxiety may be due to familial predisposition but also more general factors such as population group, gender etc. See KR Merikangas/D Pine, Genetic and Other Vulnerability Factors for Anxiety and Stress Disorders, in: KL Davis/D Charney/JT Coyle/C Nemeroff (eds), Neuropsychopharmacology - Fifth Generation of Progress (2002) $867 \mathrm{ff}$.

3 R Mason, Mad cow infected blood 'to kill 1000', The Telegraph (28 April 2013) <http://www.tele graph.co.uk/health/healthnews/10024078/Mad-cow-infected-blood-to-kill-1000.html>, accessed on 30 July 2014.

4 For instance, a mother who sees her children on the road next to a passing car will in most cases fear for their safety.

5 D Tapinos, Prévention, précaution et responsabilité civile: Risque avéré, risque suspecté et transformation du paradigme de la responsabilité civile, coll Logiques Juridiques (2008) 59. 
particularly focus on the CJD litigation ${ }^{6}$ and the decision of the House of Lords Grieves $v$ FT Everard \& Sons Ltd. ${ }^{7}$ These two key cases will be compared to provide an understanding of the general principles underpinning the compensation of the fear of future illness in English law.

The second section aims to provide an overview of the legal treatment of the fear of future illness in French law. It will provide an analysis of the French defective pacemaker litigation ${ }^{8}$ as well as the relay-antenna ${ }^{9}$ and asbestos cases. ${ }^{10}$

The third proposes a basic set of requirements that should be recognised in both legal systems to prevent unsubstantiated claims from being successful without requiring a level of proof too stringent for claimants. The current control mechanisms will be compared to the proposed requirements to determine whether their implementation would be sustainable.

The final section of this study suggests that further work be undertaken to search for an adequate balance.

\section{The general principles in English tort law}

\section{A The definition of a damage}

In Grieves $v$ FT Everard \& Sons Ltd $^{11}$ and conjoined appeals, ${ }^{12}$ the appellants who worked in contact with asbestos all developed pleural plaques as a result. Pleural plaques are asymptomatic and do not seem to cause any impairment of the physical condition. They indicate a past exposure to asbestos and, as a conse-

6 Group B Plaintiffs v Medical Research Council [1997] 41 Butterworths Medico-Legal Reports (BMLR) 157 (Queen's Bench, QB).

7 Grieves v FT Everard \& Sons Ltd [2007] United Kingdom House of Lords (UKHL) 39, [2008] 1 Appeal Cases (AC) 281 (House of Lords, HL).

8 Cour de cassation, Chambre civile (Cass civ) 1, 19 December 2006, no ${ }^{\circ} 05-15716$ and conjoined appeals (unreported). <http://www.legifrance.gouv.fr/rechJuriJudi.do?reprise=true\&page=1>accessed on 31 July 2014.

9 Cour d'appel (CA) Versailles, 4 February 2009, no 08/08775. <http://www.legifrance.gouv.fr/ affichJuriJudi.do?oldAction=rechJuriJudi\&idTexte=JURITEXT000020689588\&fastReqI

$\mathrm{d}=1221448063 \&$ fastPos=3>, accessed on 31 July 2014.

10 Cour de cassation, Chambre sociale (Cass soc) 11 May 2010, Bulletin (Bull) 2010, V, no 106, pourvoi no 09-42241 and joined appeals. <http://www.legifrance.gouv.fr/affichJuriJudi.do? oldAction=rechJuriJudi\&idTexte=JURITEXT000022214719\&fastReqId=1326573549\&fastPos=40>, accessed on 31 July 2014.

11 Grieves $v$ FT Everard \& Sons Ltd (fn 7) [7]-[11] (Lord Hoffmann).

12 Johnston v NEI International Combustions Ltd, Rothwell v Chemical and Insulating Company Ltd and Others [2007] UKHL 39, [2008] 1 AC 281 (HL). 
quence, a risk of developing asbestos-related illnesses in the future. ${ }^{13}$ The appellants sued their employers for the negligent exposure to asbestos and claimed damages with respect to the pleural plaques they had developed as well as the anxiety they felt at the possibility of contracting a lethal disease such as asbestosis or mesothelioma. A successful action in negligence requires multiple prerequisites to be fulfilled: a duty of care, a breach of this duty, damage and a causal link between the breach of the duty of care and the damage. ${ }^{14}$

In this particular case, the existence of damage was in question. More specifically, one of the main legal issues was whether or not pleural plaques could constitute actionable damage by themselves. If they could not, the issue was whether or not the association of pleural plaques and anxiety could constitute actionable damage even though neither pleural plaques nor anxiety could be actionable on their own (the aggregation theory). As such this case directly raised the question of the legal definition of damage. In an attempt to answer this question, Lord Hoffmann, approved by Lord Hope, ${ }^{15}$ stated: ${ }^{16}$

Damage in this sense is an abstract concept of being worse off, physically or economically, so that compensation is an appropriate remedy. It does not mean simply a physical change, which is consistent with making one better, as in the case of a successful operation, or with being neutral, having no perceptible effect upon one's health or capability. How much worse off must one be? An action for compensation should not be set in motion on account of a trivial injury. De minimis non curat lex. But whether an injury is sufficiently serious to found a claim for compensation or too trivial to justify a remedy is a question of degree. Because people do not often go to the trouble of bringing actions to recover damages for trivial injuries, the question of how trivial is trivial has seldom arisen directly.

For the House of Lords (now the Supreme Court), trivial, petty or minimal damage cannot be considered as recoverable damage. Given that pleural plaques were asymptomatic and although they constituted a physical change, the Law Lords considered that they did not amount to a sufficiently serious injury to be considered as damage. ${ }^{17}$

13 British Thoracic Society, Pleural Plaques - Information for Health Care Professionals [2011] 1. <https://www.brit-thoracic.org.uk/document-library/clinical-information/mesothelioma/pleur al-plaques-information-for-health-care-professionals/ >, accessed on 1 August 2014.

14 S Deakin/A Johnston/B Markesinis, Markesinis and Deakin's Tort Law (7th edn 2012) 112f.

15 Grieves $v$ FT Everard \& Sons Ltd (fn 7) [39] (Lord Hope).

16 Grieves $v$ FT Everard \& Sons Ltd (fn 7) [7]-[8] (Lord Hoffmann).

17 A Gore, What is Actionable Damage? The Demise of the Pleural Plaque Litigation (2008) 1 Journal of Personal Injury Law (JPIL) 1-15, 5; See also A McKenna, An Overview of the Legal Landscape of Negligently Inflicted Asbestos Related Conditions (2011) 4 JPIL 205, 212. 


\section{B The legal treatment of anxiety}

It has been a long-standing view that injured feelings cannot constitute a cause of action on their own: 'Mental pain or anxiety the law cannot value, and does not pretend to redress, when the unlawful act complained of causes that alone'. ${ }^{18}$

Thus it would seem that the recovery of damages for the negligent creation of a fear of future illness would be impossible. However the law has allowed the compensation of anxiety in two instances: (1) in cases where the fear of future illness is associated with physical injury and (2) in cases where anxiety is an element of a psychological injury.

\section{The fear of future illness associated with physical injury}

It has been recognised that anxiety due to the potential future consequences of an actual physical injury ${ }^{19}$ can be compensated. This is the 'single action rule' according to which: 'if a claimant has suffered actionable personal injury as a result of the defendant's breach of duty, he can and must claim damages in the same action for all the damage which he has suffered or will suffer in consequence of that breach of duty' ${ }^{20}$

This explains why the appellants in Grieves tried to prove that pleural plaques were physical damage since they would then have been able to also recover damages for their anxiety. However, given that the judges ruled out the existence of physical damage, the appellants were destined to fail in their action (except for Mr Grieves, whose case was a little different).

The appellants also tried to argue that, even though pleural plaques did not constitute physical damage, and even though anxiety on its own could not be recovered, the aggregation of the pleural plaques and anxiety together should allow for recovery since the damage suffered would pass the threshold of de minimis. However this argument proved to be unsuccessful. The judges took the view that zero plus zero equals zero, ${ }^{21}$ meaning that, since no cause of action

18 Lynch v Knight [1861] 9 Clark \& Finnelly's House of Lords Reports New Series (HLC) 577, 11 English Reports (ER) 854, at [598] (Lord Wensleydale). Affirmed in Hinz v Berry [1970] 2 QB 40, [42] (Lord Denning MR).

19 MA Jones, Liability for Fear of Future Disease? (2008) PN $2 \S 14$.

20 Grieves $v$ FT Everard \& Sons Ltd (fn 7) [13] (Lord Hoffmann).

21 Grieves $v$ FT Everard \& Sons Ltd (fn 7) [42] (Lord Hope); B Barrett, Zero + zero + zero = zero (case comment) (2009) 3 Journal of Business Law (JBL) 229, 235. 
arises from the pleural plaques or the anxiety on their own, the aggregation of the two cannot logically give rise to a cause of action. ${ }^{22}$

\section{The fear of future illness considered as psychiatric harm}

Though English law does not allow mere anxiety to be recovered, a more serious and prolonged psychiatric condition can lead to compensation.

These clinically diagnosed conditions - such as post-traumatic disorder stress, depression and other types of anxieties - need to be identified with the help of medical expertise on the basis of criteria recognised in the Diagnostic and Statistical Manual of Mental Disorders, Fourth edition (also called DSM-IV) and the International Statistical Classification of Mental and Behavioural Disorders (also called ICD-10).

In Grieves v FT Everard \& Sons Ltd, Mr Grieves' case was different from those of the other employees who suffered from anxiety only. He actually suffered from clinical depression, identified with reference to DSM-IV, and as such sustained psychiatric harm which is a form of damage recognised in English law. In relation to Mr Grieves' case the question was not whether he suffered damage, which he did, but rather whether his employer owed him a duty of care in relation to the psychiatric illness caused by his anxiety at the risk of future illness.

\section{a The distinction between primary and secondary victims}

The understanding of this case relies on the distinction first drawn in Alcock $v$ Chief Constable of South Yorkshire ${ }^{23}$ between primary and secondary victims. A primary victim is defined as 'one who was involved, either mediately or immediately as a participant' ${ }^{24}$ whereas a secondary victim is 'someone who was a passive and unwilling witness of injury caused to others'. ${ }^{25}$

Although the definition may have changed with subsequent cases it is generally recognised that a primary victim is 'one who suffers psychiatric injury after being directly involved in an accident and is either himself physically injured or put in fear of injury'. ${ }^{26}$ A secondary victim is by contrast a victim who suffers psychiatric harm as a consequence of witnessing or being informed about an

22 Grieves $v$ FT Everard \& Sons Ltd (fn 7) [14] (Lord Hoffmann).

23 Alcockv Chief Constable of South Yorkshire [1992] 1 AC 310 (HL).

24 Ibid, 407 (Lord Oliver)

25 Ibid, 407 (Lord Oliver).

26 Deakin/Johnston/Markesinis (fn 14) 125. 
accident which involves another. Claims related to the fear of future illness do not generally involve secondary victims as the definition stands.

\section{b The legal treatment of the fear of future illness in Grieves $\mathbf{v}$ FT Everard \& Sons Ltd}

Mr Grieves had been working in contact with asbestos and had developed clinical depression after being told he had pleural plaques. Given his status as an employee, there was no doubt that Mr Grieves should be considered as a primary victim. However, even as a primary victim, the establishment of a duty of care depended on what type of primary victim he was. More specifically Mr Grieves tried to establish that he should be considered as a Page $v$ Smith $^{27}$ victim which would allow him to prove that his employers should have foreseen that their negligence could put him at risk of physical or psychiatric injury. If the judges were to consider that he fitted the profile of the Page $v$ Smith victim, it would have been a lot easier for him to pass the test of foreseeability (the first step being to establish a duty of care). Mr Grieves would have had the opportunity to prove that his employer should have foreseen the risk of physical injury rather than proving that his employer should have foreseen the risk of psychiatric harm. This would have considerably eased his burden of proof.

In Page $v$ Smith the defendant was driving carelessly and caused a collision between his car and the claimant's car. The claimant did not sustain any physical injury but suffered a reaction which caused the recurrence of a prior condition, leaving him unable to work. ${ }^{28}$ Giving the leading speech, Lord Lloyd said that, in the case of a primary victim, who is directly involved in an accident, the claimant does not have to prove that the defendant should have foreseen the claimant's psychiatric harm. The claimant could prove that the defendant should have foreseen either physical or psychological harm. This case has been widely criticised as Lord Hoffmann points out in his leading judgment in Grieves $v$ FT Everard \& Sons $\mathrm{Ltd} .{ }^{29}$ Given the prospect that extensive reliance on this reasoning could lead to an opening of the 'floodgates' of litigation, ${ }^{30}$ it is not surprising that the Law

27 Page $v$ Smith [1996] 1 AC 155. See $S$ Bailey/D Nolan, The Page v Smith Saga: A Tale of Inauspicious Origins and Unintended Consequences (2010) 69(3) Cambridge Law Journal (CLJ) 495.

28 The claimant, Mr Page, suffered from myalgic encephalomyelitis (ME), also known as chronic fatigue syndrome, before his accident. After the car collision, this condition recurred.

29 Grieves $v$ FT Everard \& Sons Ltd (fn 7) [32] (Lord Hoffmann).

30 The floodgate argument refers here to the idea that the courts would be 'flooded' by many claims if the Page $v$ Smith reasoning was to be applied too extensively. 
Lords sought to distinguish Mr Grieves' case from that of the claimant in Page $v$ Smith. ${ }^{31}$ For Lord Hoffmann, Page $v$ Smith was confined to: ${ }^{32}$

a foreseeable event (a collision) which, viewed in prospect, was such as might cause physical injury or psychiatric injury or both. Where such an event has in fact happened and caused psychiatric injury, the House decided that it is unnecessary to ask whether it was foreseeable that what actually happened would have that consequence. Either form of injury is recoverable.

The main point in Page $v$ Smith was that the event (namely, the collision) had occurred. However in Mr Grieves' case, the event (that is, the development of an asbestos-related disease) had not occurred. For Lord Hoffmann, there was no doubt that, had the event occurred, it would have caused physical as well as psychological harm. But since that was not the case, Lord Hoffmann determined that the psychiatric harm suffered by the appellant was actually due to anxiety that the event could occur and not to its actual occurrence. According to him, this difference is sufficient to draw a distinction between the two cases.

Lord Hope also decided in favour of the distinction between the two cases but for two different reasons. His first reason was that the psychological damage suffered by Mr Grieves was not the result of a stressful event caused by the breach of duty. The breach of duty was the negligent exposure to asbestos during the period that Mr Grieves was working. Although Mr Grieves seemed to have a longstanding fear of contracting an asbestos-related disease, he only became really ill following the discovery of pleural plaques in his body twenty years after the exposure. The argument here is time-related. In Page $v$ Smith, the claimant suffered from psychiatric harm in the immediate aftermath of the breach of duty. In Grieves, the appellant suffered from the psychiatric illness twenty years after the negligent exposure. ${ }^{33}$ The fact that the psychological damage followed immediately on from the breach of duty seems to be an important trait of the Page $v$ Smith type of victim. The second reason is related to the absence of a causal chain between the breach of duty and the psychological damage. The psychiatric illness suffered by Mr Grieves was actually not the result of the breach of duty but his learning of the development of pleural plaques. As such, his psychological illness was due to risk and not stress as Lord Hope put it.

$31 \mathrm{~J}$ Steele, Pleural Plaques in the House of Lords: The Implications for Page $v$ Smith (case comment) (2008) 67(1) CLJ 28-30, $29 \mathrm{f}$.

32 Grieves v FT Everard \& Sons Ltd (fn 7) [32] (Lord Hoffmann). See Bailey/Nolan (2010) 69(3) CLJ 495, $521 \mathrm{f}$.

33 Grieves $v$ FT Everard \& Sons Ltd (fn 7) [54] (Lord Hope). 
A criticism of the argument made by Lord Hope is that Mr Grieves would never have suffered - and therefore learnt that he had - pleural plaques if he had not been negligently exposed to asbestos. As such it could be argued that there is a causal link between the breach of the duty and Mr Grieves' psychological damage. However, it would seem that the consequence would be too distant from the breach of duty to be taken into account by the law. The damage would probably be considered as being too remote.

The constriction of the precedent created by Page $v$ Smith is a necessary control mechanism with respect to the claims for psychological injury. Although the need to constrict the Page $v$ Smith reasoning is understandable, the decision reached by the Law Lords in Grieves remains unsatisfactory. A comparison of Page $v$ Smith with the Grieves case gives the following result: an immediate emotional (and maybe irrational) response to a stressful event which did not result in any physical harm (Page $v$ Smith) seems better legally protected than a long enduring emotional response to an event which might actually result in a serious and grave illness (the Grieves case).

Given that Mr Grieves had failed to convince the judges that he should be part of the Page $v$ Smith category of primary victim, he then tried to establish that he was owed a duty of care according to the principles of the 'stress-at-work' type of victim. ${ }^{34}$ Lord Hoffmann agreed that Mr Grieves' claim should be examined according to the principles laid down in Hatton $v$ Sutherland ${ }^{35}$ by Hale LJ. He considered that the principles of this case could be applied for any type of breach of duty by the employer. In Hatton $v$ Sutherland Hale LJ determined that the threshold question was whether 'this kind of harm to this particular employee was reasonably foreseeable'. ${ }^{36}$ In other words Mr Grieves had to prove that his employer should have foreseen his psychiatric injury with regard to his particular personality. However in the absence of any knowledge of an employee's particular vulnerability, the employer was entitled to assume that he was of normal fortitude. Lord Hoffmann considered that it was fairly unlikely that the employer could have had any knowledge of the potential reaction of its employee concerning the risk of an asbestos-related disease thirty years after he left employment. Consequently, his employer was entitled to consider Mr Grieves as an employee of normal fortitude. In order to pass the test, Mr Grieves had to prove that it was reasonably foreseeable that the event which actually happened (namely, the creation of a risk of an asbestos-related disease) could have caused a psychiatric

34 D Leczykiewicz, Pleural Plaques, The Concept of Damage and Liability for Psychiatric Injury (case comment) (2008) 124 Law Quarterly Review (LQR) 548, 551.

35 Hatton $v$ Sutherland [2002] Court of Appeal (Civil Division) (EWCA Civ) 76 (CA).

36 Hatton $v$ Sutherland [2002] EWCA Civ 76 (CA), [23]. 
injury in an employee of normal fortitude. Lord Hoffmann following the Court of Appeal noted that there was no basis for such a finding and dismissed the claim.

Grieves $v$ FT Everard \& Sons shows that the Law Lords' approach to the fear of future illness with regard to psychiatric harm is rather cautious to say the least. The conditions of a duty of care in relation to psychiatric harm are rigorously examined and Page $v$ Smith, which establishes a more flexible approach, is confined as much as possible, although the judges in Grieves dared not overrule its core principle. It is interesting to compare this decision with the CJD (Group $B$ Plaintiffs) where the High Court had previously taken a more flexible approach. A comparison of these two cases reveals the reasons why the claimants in Grieves were distinguished from those in the CJD litigation.

\section{c The legal treatment of the fear of future illness in Group B Plaintiffs v Medical Research Council ${ }^{37}$}

In CJD Litigation, Group B Plaintiffs v Medical Research Council, the plaintiffs, children affected by dwarfism, were given a human growth hormone (Hartree $\mathrm{HGH}$ ) that exposed them to the risk of contracting Creutzfeldt-Jakob disease (CJD) as it was donated from human subjects. After being informed of this possibility, the plaintiffs sought compensation for the psychiatric illness they suffered due to the knowledge of this potential risk.

As in the subsequent case of Grieves $v$ FT Everard \& Sons Ltd, the claimants tried to prove that they fitted the Page $v$ Smith category of primary victims. ${ }^{38}$ In the event that Page $v$ Smith was distinguished from their case, they also submitted that the defendants should have foreseen that the Group B Plaintiffs, as plaintiffs of ordinary fortitude, might have developed a psychiatric illness on becoming aware of the CJD risk.

The judge, Morland J, decided that the situation of the Group B plaintiffs was very different from that of the claimant in Page $v$ Smith. He gave three reasons for drawing a distinction.

The first reason was that, in Page $v$ Smith, the claimant became aware of the danger before the physical event (namely, the car accident) occurred. However in the CJD litigation, the plaintiffs became aware of the danger after the occurrence of the physical event (that is, the injection of $\mathrm{HGH}$ ). As in Grieves $v$ FT Everard \&

37 Group B Plaintiffs $v$ Medical Research Council [1997] 41 BMLR 157 (QB).

38 See M Mildred, The Human Growth Hormone (Creutzfeldt-Jakob Disease) Litigation (1998) JPIL 251, $264 \mathrm{ff}$. 
Sons Ltd, the moment where the claimants become aware of the danger seems to be the cornerstone of the distinction.

The second reason was that in the CJD litigation the claimants' psychiatric injury was not triggered by the physical event per se, again in contrast with Page $v$ Smith. It was not disputed that the injection of Hartree HGH was an important causal factor in the psychiatric illness but Morland J considered that it was actually their awareness of the risk which triggered it. As can be observed, the two first reasons given by Morland J seem to have been approved by Lord Hope in the asbestos case.

The last reason, and perhaps the most important for Morland J, was related to public policy. He anticipated that if the distinction between the two cases was not drawn, it would set a precedent which would undoubtedly be used by other types of claimants in a similar situation (asbestos and radiation cases). In these contexts, the use of Page $v$ Smith would open the floodgates for potentially huge numbers of claims to arise. He thought that it would have disastrous consequences such as making it difficult or impossible for the defendants to obtain insurance and the possible inhibition of prevention measures: Morland J feared that if cases where claims in relation to the fear of future illness were easily successful, companies might hesitate to warn the public of the dangers of a product for fear of having to pay damages. Although Lord Hoffmann seemed to doubt the consequences predicted, he agreed that the use of Page v Smith in the asbestos scenario would extend the principle beyond its original purpose.

Morland J then turned to the second submission made by the claimants and examined the existence of a duty of care according to the traditional test set out in Caparo Industries plc $v$ Dickman. ${ }^{39}$ That case laid out three conditions to determine the existence of a duty of care: harm must be reasonably foreseeable as a result of the defendant's conduct; the parties must be in a relationship of close proximity; and it must be fair, just and reasonable to impose liability on the defendant.

With regard to the first condition, the claimants had to prove that in light of the available knowledge on the relevant date (1 July 1977), the defendants should have foreseen that the risk of CJD becoming a reality could occur within a period of time, whether one, two or ten years after the injection. This requirement was closely examined by Morland $\mathrm{J}$ as it was the focal point of the disagreement between the parties. He stated that: ${ }^{40}$

39 Caparo Industries plc v Dickman [1990] UKHL 2.

40 Group B Plaintiffs $v$ Medical Research Council [1997] 41 BMLR 157 (QB), [165]-[166] (Morland J). 
Although it may not be reasonably foreseeable that the man of ordinary fortitude would develop psychiatric illness if the information that he was at slight theoretical risk of CJD was given to him by a doctor or counsellor, who would no doubt give the information with optimistic stress, however, in the case of a special therapeutic trial or programme as the HGH programme, it should have been reasonably foreseeable to the defendants by 1 July 1977 that, when news of the potential risk of CJD broke to those who were or had been children when treated, the news would reach Group B plaintiffs not only from considerate and skilled clinicians and counsellors, but also from the media, which foreseeably would tend to highlight or sensationalise the risk of the potential terrible outcome, and from anxious and perhaps angry relations and friends, who would be ignorant of scientific knowledge and likely to use unhelpful language.

Morland J considered that the defendants should have foreseen that the risk of CJD becoming a reality could occur within a broad period of time. He added that it was then foreseeable that the patients would learn the news from the media which would sensationalise the risk of CJD in a frightening way. In these circumstances the defendants should have foreseen psychiatric harm. However Morland J probably realised that his decision could result in the success of similar claims (for instance, in asbestos and radiation cases). To avoid this outcome he stated that, except for cases of therapeutic programmes (such as the HGH programme), it was not foreseeable that a man of ordinary fortitude would develop psychiatric illness upon learning such news from his doctor. We believe that this specification allows for the CJD litigation to be distinguished from other similar cases such as asbestos or radiation. The people who work in contact with asbestos are not part of a therapeutic programme and they usually learn the news of the risk of contracting a disease from their doctors. Morland J stated clearly that psychiatric harm would not be foreseeable in these situations.

With regard to the second condition laid out in Caparo Industries plc $v$ Dickman, Morland J considered that the relationship between the parties was akin to one between doctor and patient. As such there was a relationship of close proximity between the parties.

With regard to the last condition, the judge considered that there was no valid reason of public policy which prevented the recognition of a duty of care. The number of potential claimants was quite small since only children who received Hartree HGH after 1 July 1977 had a cause of action. As such, it was a small 'cohort' and there was no risk of opening the floodgates. The Supreme Court used this argument in Grieves v FT Everard \& Sons Ltd to distinguish the two cases since the potential number of claimants in asbestos-related claims is rather large.

The judge in the $C J D$ case took a flexible view to compensation of psychiatric harm in relation to the fear of contracting a future illness. However it seems quite clear that this was mainly due to the specific facts of the case. As such the approach taken by the judges in this case seems rather exceptional and is probably not 
indicative of the general view taken in relation to claims of anxiety. The claimant in Grieves $v$ FT Everard \& Sons Ltd tried, without any success, to rely on both Page $v$ Smith and the CJD case for compensation for his psychiatric harm. The first step to distinguish the Page $v$ Smith claimants from the 'fear of future illness' claimants had been taken in the CJD case. Hence it was not surprising that this argument proved unsuccessful in the asbestos claim. However, Mr Grieves apparently hoped that his reliance on the $C J D$ litigation would be better welcomed despite Morland J's best effort to prevent this possibility from materialising. The Supreme Court made quite sure that this door was also closed to claimants. Consequently, without actual physical harm, claims in relation to the fear of contracting a future illness are rarely successful in English law. In contrast, French law proves much more flexible in this respect and has even recognised anxiety as a specific form of damage. The striking similarities between the facts of the asbestos cases in French and English law will be used to understand the difference of approach.

\section{The general principles in French tort law}

\section{A The definition of damage}

As in English law, certain requirements need to be met for an action in negligence to be successful: fault, damage and a causal link between the fault and the damage. ${ }^{41}$ These concepts are understood rather loosely and are not given any generally accepted definition. ${ }^{42}$ However they have specific characteristics which enable the court to determine whether or not they exist. Damage is usually said to have four characteristics: ${ }^{43}$ it needs to be certain, direct, personal and constitute a violation of a legitimate interest, although the courts generally advert to the first two criteria only. ${ }^{44}$

The condition of certainty does not mean that only actual damage can be recovered. Future damage can also be compensated if it can be considered as certain. ${ }^{45}$ The distinction between certain damage and uncertain damage becomes apparent in cases of loss of chance. ${ }^{46}$ Under French law, if a candidate fails

41 See arts 1382 and 1383 of the Civil Code.

42 Concerning the difficulty in defining the concept of fault, see J Flour/J-L Aubert/E Savaux, Droit civil - Les obligations - Le fait juridique (13th edn 2009) $112 \mathrm{ff}$.

43 P Conte, Responsabilité du fait personnel, Répertoire du droit civil (May 2002) § 225.

44 Eg Cass Civ 1, 30 April 2014, no 13-16.380 (unreported).

45 Y Lequette/P Simler/F Terré, Droit civil - Les obligations (11th edn 2013) 758.

46 A Bénabent, Droit des obligations (14th edn 2014) $493 \mathrm{ff}$. 
to take an exam because of someone's wrongdoing, they will be entitled to recover damages for their lost chance of success depending on their previous academic records. Cases of loss of chance are successful as long as the chance is real and serious. ${ }^{47}$

The requirement for the damage to be direct simply means that the damage has to be the direct consequence of the event giving rise to a cause of action. This is another way of saying that there needs to be a sufficient causal link between the fault and the damage. ${ }^{48}$ Therefore this criterion can also refer to the condition of a causal link. As such it is sometimes said that the condition of direct damage repeats the condition of a causal link ${ }^{49}$ It is interesting to note that there has been a controversy in English law with regards to whether the damage needed to be direct or foreseeable. In 1921, the Polemis case ${ }^{50}$ indicated that the defendant was to be held liable for all the direct consequences of his negligence even though the damage was unforeseeable. But the uncertainty about the criteria to be used was subsequently settled in favour of the foreseeability of the damage in two Privy Council decisions, Wagon Mound Nos ${ }^{\circ} 1$ and 2.51

No real explanation is usually offered by the Supreme judges in France to justify why the damage is considered to be certain or direct even though they tend to give a more detailed explanation when it is not certain or direct.

\section{B The legal treatment of anxiety}

Compensation for physical and material damage is widely accepted in French law. In contrast, compensation for psychological damage has been debated because damages are not believed to be an appropriate remedy. ${ }^{52}$ Moral damage refers to the idea of psychological pain felt, for instance, on the loss of a close relative, although it has also been recognised for the loss of pets. ${ }^{53}$ In French law there is no legal principle preventing the recovery of damages in cases of purely psychological injury, contrary to English law. It would thus seem that nothing

47 See eg Cass Civ 2, 4 May 1972, Dalloz (D) 1972, 596, obs P Letourneau.

48 Bénabent (fn 46) 490.

49 Lequette/Simler/Terré (fn 45) 762.

50 Polemis v Furness Withy \& Co Ltd [1921] 3 KB 560; J Steele, Tort Law: Text, Cases and Materials (2nd edn 2010) 182.

51 Overseas Tankship (UK) Ltd v Morts Dock and Engineering Co Ltd (The Wagon Mound (No 1)) [1961] AC 388 and Overseas Tankship (UK) Ltd $v$ The Miller Steamship Co (The Wagon Mound (No 2)) [1967] 1 AC 617; Steele (fn 50) $183 \S 6$.

52 See Aubert/Flour/Savaux (fn 42) $161 \mathrm{ff}$.

53 Famous case about the horse called Lunus: Cass civ 1, 16 January 1962, no 33 (published). 
would in principle prevent French law from compensating anxiety. ${ }^{54}$ It has long been recognised that the anxiety associated with physical damage can be compensated in French law. It seems that there is no difference between the French and English legal systems on this point. However even without its coexistence with material damage, compensation for psychological damage has been accepted in the case of a person fearing imminent death. ${ }^{55}$

\section{The first step for the recognition of préjudice spécifique d'anxiété (specific damage of anxiety): the pacemaker litigation ${ }^{56}$}

The claimants had all received a pacemaker implant due to their heart conditions. However the company who manufactured the products had to issue a recall after being informed that some of them had broken. None of the claimants' pacemakers had failed but they decided to have them explanted and replaced as a precautionary measure. They claimed damages in relation to the defect in the product as well as the anxiety related to the risk of failure.

The Cour de cassation (Supreme Court of France) was then faced with two issues. The first was to determine whether the claimants could claim damages for the replacement of their pacemaker. The second was related to the anxiety they felt due to the knowledge of the pacemaker's potential failure.

In relation to the first issue, the Cour de cassation decided in 2006 to reject the claims. ${ }^{57}$ Two arguments guided the judges' decision. Firstly the claimants

54 P Jourdain, Les préjudices d'angoisse, La Semaine juridique, édition générale (JCP G) no 25 , 22 June 2015, doctr 739: ‘Tout au contraire, le droit français n'oppose aucune limite à la réparation, tout dommage, et notamment tout dommage moral, étant a priori réparable'.

55 Cour de cassation, Chambre criminelle (Cass crim) 23 October 2012, Revue responsabilité civile et assurances (RCA) 2013, comm 2; Revue trimestrielle de droit civil (RTD civ) 2013, 125, obs $P$ Jourdain.

56 Cass civ 1, 19 December 2006, no05-15716 (fn 8).

57 It is interesting to note the position of the European Court of Justice (ECJ) on a very similar issue in joined cases C-503/13 and C-504/13, Boston Scientific Medizintechnik GmbH v AOK Sachsen-Anhalt - Die Gesundheitskasse and others, Official Journal (OJ) L 138, 27.4.2015, 9-10 (ECLI:EU:C:2015:148); ECJ, C 138/9 (4th chamber) paras 1-56. The Bundesgerichtshof (Federal Court of Justice of Germany) made a request to the ECJ for a preliminary ruling on the interpretation of art 1, 6(1) and sec (a) of the first paragraph of art 9 of Council Directive 85/374/EEC of 25 July 1985 on the approximation of the laws, regulations and administrative provisions of the Member States concerning liability for a defective product, OJ L 210, 7.8.1985, 29-33. In this case, two claimants who were implanted with potentially defective pacemakers had them explanted and replaced. Damages were claimed to reimburse the costs relating to the claimants' treatment. The Bundesgerichtshof decided that the solution of this case depended on whether the pace- 
were supposed to have had increased medical supervision to check on the functioning of their pacemakers but decided instead to have the defective product replaced. They did not prove that the replacement was necessary. In fact the risk of having the pacemaker replaced was higher than the risk of keeping the defective one. Secondly the surgery required to replace the pacemaker did not result in any damage. The judges considered that the claimants' damage was not certain. ${ }^{58}$

In connection with the second issue, the Supreme Court judges decided in favour of the claimants. They agreed that, until the pacemaker was replaced, the claimants were suffering from anxiety. However the Cour de cassation did not recognise anxiety as a specific head of damage and decided that anxiety should be compensated as part of the more general category of non-material loss. The words used in the judgment, as well as the fact that it is unreported, seem to indicate that this decision was based on the specific facts of the case. ${ }^{59}$ As such the Cour de cassation decided to take only a very small step with this decision. It was only four years later that the Supreme Court took the decision further by recognising anxiety as a specific head of damage.

makers which were only potentially defective could be considered as defective in the meaning of art 6(1). It referred the question to the ECJ. The ECJ ruled that it was possible to classify all products of the same group as defective when it was found that such products belonging to said group had a potential defect [41]. The ECJ also decided that compensation for damage should cover the costs relating to the replacement of the defective product [50]. The position adopted by the ECJ is completely different from the position adopted by the Cour de cassation in the defective pacemaker litigation.

58 See eg Cass civ 1, 19 December 2006, no 05-15.719 (unreported): 'Attendu qu'après avoir constaté qu'il existait un défaut de conception de la sonde créant un risque de rupture du fil de rétention, que pour contrôler ce risque, il avait été convenu d'augmenter la surveillance médicale des patients porteurs de telles sondes, que le changement de sonde, effectué à titre préventif et sans preuve que cette surveillance aurait été insuffisante, n'avait pas posé de problème et que le patient avait été ainsi soumis à un risque qui ne s'était pas réalisé, la cour d'appel a pu en déduire que le préjudice invoqué avait un caractère éventuel ; que le moyen en sa première branche n'est donc pas fondé.'

59 See Cass civ 1, 19 December 2006, no05-15.719 (unreported): 'Attendu que la cour d'appel a débouté $M$. X... de sa demande d'indemnisation d'un préjudice moral sans répondre à ses conclusions invoquant l'existence d'un dommage lié à l'annonce de la défectuosité du type de sonde posée et à la crainte de subir d'autres atteintes graves jusqu'à l'explantation de sa propre sonde, méconnaissant ainsi les exigences du texte susvisé.' See commentaries: RTD civ 2007, no 2 (15 June 2007) 352ff, obs $P$ Jourdain; La Semaine juridique, édition générale (JCP G) 2007, no ${ }^{\circ} 13$ (28 March 2007) II 10052, obsS Hocquet-Berg. See also: P Brun/P Jourdain, Responsabilité civile: July 2006 - June 2007, D 2007, no 41 (29 November 2007) 2897; C Radé, Sondes cardiaques défectueuses, RCA 2007, no² (February 2007) comm 64. 


\section{The recognition of anxiety as a specific head of damage: the asbestos case-law}

In 2010, the Cour de cassation took a step further and recognised anxiety as a specific head of damage for 17 employees who had worked in contact with asbestos. ${ }^{60}$ In this case, the employees tended their resignation in order to benefit from the retirement pensions to which they were entitled due to the fact that they had to work in contact with asbestos for several years. They argued that their termination of the contract was the direct consequence of their negligent exposure to asbestos by their employer. As a result, they claimed the difference between the pensions and what they would have earned had they not retired. They also sought compensation for anxiety in relation to the possibility of suffering from an asbestos-related illness.

Occupational diseases are generally taken into account under the Code of Social Security and employees can usually claim compensation in relation to the specific illnesses listed in this Code. As such, occupational diseases are managed by specific rules and not by the general rules of civil liability. The defendant argued that, even though the employees' anxiety might warrant specific compensation, it could only intervene under the conditions prescribed in the Code of Social Security. The defendant further contended that the claim was void of substance as it did not relate to the actual existence of an occupational disease. Nonetheless the Cour de cassation decided in favour of the claimants and recognised their entitlement to compensation for the fear of future illness even though none of them suffered from an actual asbestos-related disease. As such the asbestos cases have enabled the Supreme Court to recognise a new separate head of damage specifically for anxiety. The Supreme Court's argument, which explained the creation of this new category, was that the employees were in a situation of constant worry and had to undertake tests which undoubtedly reactivated their anxiety. Subsequent cases have reaffirmed this principle in connection with asbestos. ${ }^{61}$

However the Cour de cassation left some issues unclear. Even though the decisions have since been widely published, it is difficult to know whether the recognition of this new head of damage is confined to asbestos cases only or if it was meant to be more general in scope. Subsequent cases showed that the new category could be used in other contexts too. ${ }^{62}$ For instance, on 2 July 2014 the

60 Cass soc, 11 May 2010, Bull 2010, V, no 106, pourvoi no 09-42241 and joined appeals.

61 For instance: Cass soc, 4 December 2012, Bull 2012, V, no ${ }^{\circ 316}$, pourvoi no ${ }^{\circ} 11-26294$.

62 See Cass civ 1, 2 July 2014, noำ-19.206, unreported (DES case). See also: Conseil de prud'hommes Longwy, 6 February 2015 (employees who have inhaled noxious chemicals other than 
Cour de cassation allowed compensation for the anxiety felt by a claimant exposed to Diethylbestrol (DES) while her mother was pregnant. It is a known risk that daughters exposed to DES through their pregnant mothers are at a higher risk of contracting vaginal cancer, infertility or other conditions. Did this decision mean that all claims of anxiety would be successful in case of DES? The Cour de cassation answered this question on 11 December 2014 when it decided to refuse compensation for anxiety as a specific head of damage. In this case, the claimant was a woman exposed to DES when she was a foetus. In later life she experienced difficulties in her pregnancies which she attributed to her exposure to DES. She claimed damages for the anxiety she felt due to the knowledge that she could develop a DES-related illness and for her permanent functional deficiency, including her loss in quality of life, difficulties in the conditions of her personal, social and familial existence and the psychological pain she experienced. The Court of Appeal decided to award damages to the plaintiff not only for permanent functional deficiency but also for anxiety as a specific head of damage. The Supreme Court overturned the decision of the Court Appeal with regards to her claim for anxiety ${ }^{63}$ because she could not prove that this claim was independent from her claim of permanent functional deficiency. As such, according to the rule of full redress, the claimant could not be compensated twice for the same damage.

It is interesting to note that the Cour de cassation did not refuse in principle to compensate anxiety as a specific head of damage, which confirms that this head of damage is not confined to asbestos cases only. This unreported decision is disappointing since the Cour de cassation could have taken the opportunity to attempt to define more precisely the conditions in which the fear of future illness may be recovered. However, the Supreme Court preferred to avoid the question and denied the claim based on the principle of full recovery.

The asbestos case proved to be a landmark in the legal treatment of anxiety. However, the decision (and subsequent cases) left unanswered questions regarding the conditions under which anxiety as a specific head of damage could be

asbestos): 'Les salariés ont été exposés aux poussières et inhalation de produits nocifs [...], « compte tenu de ces expositions les salariés de cette société se trouvent, par le fait de l'employeur dans une inquiétude permanente face aux risques de déclaration à tout moment d'une maladie liée à l'inhalation de produits nocifs [...] », « celui-ci doit en principe être réparé ».'

63 With regards to the claim of permanent functional deficiency, the Supreme Court judges considered that the Court of Appeal gave conflicting reasons in its judgment. On one hand, the Court of Appeal judges dismissed the claim related to the permanent functional deficiency but on the other hand they awarded damages to the plaintiff for this damage. This inconsistency was identified by the Cour de cassation, which subsequently overturned the decision of the Court of Appeal on this point too. 
compensated. The Cour de cassation's failure to answer these questions can probably be linked to its particular role in the French legal system, in which it acts as a court of cassation rather than a court of appeal on questions of both fact and law, which explains its tendency to avoid defining legal principles by dismissing issues as questions of facts for the lower courts. This failure to define appropriate control mechanisms has had important consequences as it has enabled some courts of appeal to extend the use of this head of damage beyond its original purpose.

\section{The use of anxiety as a specific head of damage in cases of suspected risk: the relay-antenna cases}

Some scientific studies have raised the question of the potential dangers of a prolonged exposure to low-frequency waves emitted by mobiles and relay-antennas. Although the validity of these studies is controversial within the scientific community, EU governments have felt the need to address these concerns. As a result, frequency levels have been strictly regulated through the implementation of the European Radio and Terminal Communications Directive 1999/5/EC. ${ }^{64}$ However, because the very existence of this risk is in question, it is said to be 'suspected' rather than 'known'. In contrast a risk is said to be 'known' when not only its existence but also its effects are known or agreed upon by the scientific community. For instance, the risk of mesothelioma due to asbestos is well-known, as are the risks associated with the consumption of Thalidomide or DES. The understanding of this difference is central to the relay-antenna cases.

Some people living in the vicinity of relay-antennas have complained of the nuisance created by this unwelcome neighbour. They have claimed damages for the fear of contracting illness due to the emission of very-low frequency waves. In other words the claimants have tried to claim damages for the anxiety related to a potential, uncertain, suspected risk. In the context of troubles anormaux de voisinage (the equivalent of private nuisance in the common law), the remedy is usually an injunction from the court to cease the nuisance. In the present context, the claimants were seeking an order to dismantle the relay-antennas in their

64 Directive 1999/5/EC of the European Parliament and of the Council of 9 March 1999 on radio equipment and telecommunications terminal equipment and the mutual recognition of their conformity, OJ L 91, 7.4.1999, 10-28. It is to be noted that this Directive will be replaced on 13 June 2016 by the Directive 2014/53/EU of the European Parliament and of the Council of 16 April 2014 on the harmonisation of the laws of the Member States relating to the making available on the market of radio equipment and repealing Directive 1999/5/EC, OJ L 153, 22.5.2014, 62-106. 
vicinity. If their claim had succeeded, it would certainly have encouraged dubious claims of anxiety in similar contexts. Most courts have rejected these claims but some of them have been successful.

One of the main issues in relation to the relay-antenna cases was determining whether civil or administrative courts had jurisdiction over the claims. The administrative courts could have jurisdiction on the ground that the implantation of a relay-antenna requires administrative authorisation. As such the dismantling of a relay-antenna should logically be ordered by the administrative courts. However, the claim here was of private nuisance between two private individuals, a natural person and a private company who owned the relay-antenna. As such, the civil courts claimed jurisdiction. This uncertainty over jurisdiction has since been settled by the Tribunal des conflits (Tribunal of conflicts, TC) which determined that administrative courts have jurisdiction over these health-related claims. ${ }^{65}$ Nevertheless prior to this matter being settled, administrative and civil courts both accepted jurisdiction. Administrative courts usually decided in favour of the company and refused to order the dismantling of the relay-antennas. In the civil courts, there was a controversy as to the correct outcome. For instance the Court of Appeal of Paris rejected the claims brought before $i^{66}$ while a claim before the Court of Appeal of Versailles proved more successful. ${ }^{67}$ It was thus difficult to predict how any particular case would be decided, which created legal uncertainty.

The Court of Appeal of Versailles crossed the line on 4 February $2009^{68}$ and ordered the dismantling of a relay-antenna as a remedy for anxiety due to the potential risk to the claimants' health. The Court concluded that it was uncertainty as to the very existence of the risk that created the anxiety. This constitutes a major difference from the previous cases studied. In the pacemaker, asbestos and DES cases, the uncertainty was related to the actual occurrence of a known risk. This was what led to the compensation. In this case, the uncertainty was related to the existence of the risk itself. The dangers of such a decision are great since it tends to threaten the coherence of tort law as a whole. In the law of civil liability, causation and damage need to be certain. What would be left of these safeguards if the courts were to start to compensate with the level of uncertainty apparent in the relay-antenna case? Unsurprisingly then, the case has attracted considerable criticism from academic commentators. ${ }^{69}$

65 TC 14 May 2012, Orange France, SFR, Bouygues telecom, Bull TC 2012, nos 12, 13, 14, 15, $16,17$.

66 CA Paris, 3 February 2010.

67 CA Versailles, 4 February 2009, no 08/08775 (fn 9).

68 Ibid.

69 See $M$ Boutonnet, Le risque, condition « de droit » de la responsabilité civile, au nom du principe de précaution? D 2009, no 12 (19.03.2009) 819; P Jourdain, Risque et préjudice (suite) : 
However the aim behind the judgment needs to be properly understood. The rules of civil liability were distorted in order to promote the prevention of physical harm. The claimants did not suffer from any physical injury and it was even uncertain that the alleged risk actually existed. Nonetheless, an injunction to dismantle the relay-antenna due to the fear of contracting a future disease was a very convenient way to prevent such potential harm. The precautionary principle has without any doubt guided the judges' decision and multiple references to it can be found within the judgment.

Additionally, the use of anxiety as a specific head of damage was a clever way to tackle the difficulty linked to causation. As has been said, the potential dangers of relay-antennas are doubted. Hence, even though the claimants could have suffered from physical harm, their case would undoubtedly have failed on the grounds of causation. However, their anxiety was clearly caused by the potential existence of the risk. To that extent it could be argued that the existence of relayantennas in the vicinity of the claimants' house was a nuisance.

As mentioned, the Court of Appeal relied on the precautionary principle in their decision in the relay-antenna case. The case did not reach the Cour de cassation, but in a similar case the Cour negated the direct use of the precautionary principle in civil liability cases in a claim relating to the alleged livestock damage from overhead power lines, ${ }^{70}$ indicating the court's reluctance to accept claims of this nature. Consequently, the relay-antenna cases cannot be said to represent the law as it stands today. However the outcomes indicate that the law of tort has undergone a major conceptual change. Its traditional functions are usually said to be compensation, deterrence and even sometimes punishment. The relay-antenna cases show that the law of tort can now be used to prevent physical harm from happening. This shows a conceptual change as to how tort law can be used, even though it seems difficult given that the rules of liability only come into play when damage has occurred. However the creation of a specific head of damage for anxiety without defined control mechanisms has opened up this new possibility. Admittedly, no claim of fear of future illness in

réparation au titre des troubles du voisinage du préjudice généré par la présence d'antenne-relais de téléphone mobile, RTD civ 2009, no 2 (15.06.2009) 327; J-P Feldman, Le trouble voisinage du principe de précaution D 2009, no 20 (14.05.2009) 1369 ; D Zmirou-Navier, L'antenne de Pandore, Gazette du Palais (GP) (24 November 2009) no³28, 8; C Quézel-Ambrunaz, Antennes-relais : distinguer risque, trouble et préjudice sur fond de principe de précaution! Revue Lamy de droit civil (RLDC) 2009, 59.

70 Cass civ 3, 18 May 2011, Bulletin des Arrêts de la Chambre Civile de la Cour de cassation (Bull civ) III, 2011, no 80, pourvoi no ${ }^{\circ} 10-17645$. See $P$ Jourdain, Principe de précaution et causalité: quelle incidence du premier sur la seconde, RTD civ 2011 no³ (14.10.2011) 540; G Forest, Responsabilité, principe de précaution et causalité, Dalloz Actualité (AJD) 30 May 2011. 
connection to the relay-antenna litigation has been successful since the decision of the Court of Appeal of Versailles on 4 February 2009. This indicates that this 'new' function of tort law cannot be used in cases of suspected, uncertain risks. However, it could be argued that tort law could still potentially be used to prevent physical harm from occurring when the risk is known.

Even though the decisions reached in the relay-antenna cases have since been superseded, they illustrate the dangers of insufficient control mechanisms with respect to compensation for the fear of future illness. This should invite more general reflection so as to understand how this could have happened and how to avoid the same situation in future. A comparison of the control mechanisms employed in both legal systems seems a suitable way of investigating further where to draw the line in compensating for the fear of future illness.

\section{A comparison of the control mechanisms in place in English and French law}

The above analysis shows that there is a disparity between how English and French law treat the fear of future illness. English law has adopted a relatively unyielding approach when compared to the more flexible approach of French law. It could be argued that neither of the approaches taken by the two legal systems is satisfactory as they are both extreme. The conditions under which claimants can recover damages for their fear of future illness are very stringent in English law. This explains why such claims are rarely successful, as Grieves $v$ FT Everard \& Sons Ltd confirms. In contrast, the absence of clear conditions defining the specific head of damage for anxiety could enable unsubstantiated claims to be successful in French law, as the relay-antenna cases showed. Consequently, this section will advance some basic propositions as to how both legal systems can best tackle the challenges arising, relating them to the control mechanisms already in place in English and French law.

\section{A The fear of future illness should be compensated only when the risk actually exists}

The first basic proposition should be that a claimant should be able to recover damages for the fear of future illness when the possibility of contracting an illness is real. This means that the risk should not only be known (as opposed to suspected) but also deemed to be serious. In other words compensation for the 
fear of future illness should be denied when the risk is either suspected or known but unlikely to occur, which can be explained on the basis that, in both instances, the fear of future illness is objectively without substance and arises only because of personal susceptibility to anxiety.

English and French case law do not expressly require that the risk be known and serious, but the relay-antenna cases prove the need for an express stipulation to this effect in French law. Admittedly, after the controversial decision of the Court of Appeal of Versailles on 4 February 2009, no other attempt has been made to recover damages for the fear of future illness in the case of merely suspected risks. But since the Supreme Court of France has not explicitly defined the conditions for the application of this specific head of damage, it is only a matter of time before the issue is raised again.

These requirements do not exist in English law, but other control mechanisms make it impossible for a claim to be successful if the existence of the risk is not certain. If the existence of the risk is in question, claimants would find it difficult to prove that their psychiatric harm should have been foreseen by the defendant. The condition of foreseeability would also bar claimants from recovering damages if the risk is known but unlikely to occur. To that extent, the requirement of foreseeability of harm is a powerful control mechanism in itself.

\section{B The fear of future illness should be compensated only if anxiety is adequately proven}

One of the striking differences between the legal treatment of anxiety in French and English law relates to the level of proof of anxiety required.

Compensation can be claimed under French law if the claimant only suffers from simple anxiety. Common sense is usually relied upon by judges to distinguish what should be compensated from what should not. In contrast, claimants can only recover damages in English law if they can prove that they suffer from a diagnosed psychiatric illness. This more stringent requirement draws the line between simple anxiety (no compensation) and actual damage (compensation).

Thus it should be discussed what is the appropriate level of proof needed to strike an adequate balance between the interests of claimants and defendants.

In this section it is argued that the level of proof required in both legal systems is unsatisfactory and fails to strike an appropriate balance between the interests of the opposing parties. More specifically, it is contended that the level of proof required in French law is too low. In the asbestos context for instance, the existence of simple anxiety can be recognised through the use of presumptions. 
As such the level of proof required is too favourable to the claimants (see 1 below). Thereafter it is argued that the threshold of a recognised psychiatric illness required in English law is too stringent. The existence of other control mechanisms in tort law is sufficient to prevent claims from succeeding too easily. The level of proof required is therefore unnecessarily high (see 2 below).

This comparison provides the basis for further demonstration of the adequacy of the level of proof advocated here.

\section{The recognition of simple anxiety through the possible use of presumptions in French law: an excessively low level of proof}

On 4 December 2012, ${ }^{71}$ subsequently confirmed in $2013^{72}$ and $2014^{73}$, the Cour de cassation examined a case where employees who worked in contact with asbestos claimed damages for their anxiety as a specific head of damage. The defendants, who prevailed before the Court of Appeal, argued that their claim should be rejected on the ground that the claimants did not bring forward any evidence of the damage. They did not provide any proof of their alleged anxiety or of any medical treatment. The Cour de cassation overturned the decision of the Court of Appeal. They decided that, since the employees fulfilled the conditions required to benefit from an earlier retirement pension due to the fact that they worked in contact with asbestos ${ }^{74}$, and since the company in which they worked for was specifically listed in the applicable legislation ${ }^{75}$, the claimants could legally claim damages for their anxiety as a specific head of damage. Once the claimant has proved these conditions, anxiety is recognised de facto as a specific head of damage. The Supreme Court drew a factual inference of anxiety from the fact that these two conditions were indeed met. It can be doubted that this inference could be challenged by the defendant. This outcome most likely reflected a public policy of improving the compensation available to asbestos workers. The conditions under which the inference is drawn suggest that it is confined to asbestos cases only.

However as reflected in a number of decisions on 3 March 2015, the Cour de cassation seems to have since taken a more rigorous approach to the compensa-

71 Cass soc, 4 December 2012, Bull 2012, V, no³16, pourvoi no¹1-26294.

72 Cass soc, 25 September 2013, nos ${ }^{\circ} 12-12883,12-13307$.

73 Cass soc, 2 April 2014, no¹2-29825.

74 These conditions are enumerated in art 41 of loi no98-1194 of 23 December 1998.

75 The workers need to have worked in a company specifically listed in 'arrêté ministériel' of 29 March 1999 (modified). 
tion of anxiety for asbestos workers. ${ }^{76}$ In one of four published cases, ${ }^{77}$ the Cour de cassation decided to bar compensation for anxiety on the part of asbestos workers who had not worked in a company specifically listed in the relevant statute. ${ }^{78}$ The Court of Appeal had nevertheless decided that the workers could still recover damages for their anxiety if they could prove that they had been exposed to asbestos by their employers. The Cour de cassation overturned this decision, however, and refused the benefit of compensation to the claimants. This shift of position from the Supreme Court is undoubtedly an attempt to limit the extensive use of the specific head of damage for anxiety that had become possible over the past years. Once again, however, the Cour de cassation refused to delineate clearly the boundaries of this controversial head of damage, preferring to proceed on a case by case basis. ${ }^{79}$ It can be argued that this new position for asbestos workers is not justified: strong control mechanisms alone should be enough to prevent an uncontrollable rise in claims.

Following the decisions, compensation for anxiety suffered by asbestos workers may be summarised as follows. Employees who have worked in a company specifically listed in the applicable legislation can be compensated for their fear of future illness without the need to prove their anxiety. This presumption still stands for these workers as one of the decisions given on 3 March 2015 confirms. $^{80}$ However, employees who have worked in a company which is not specifically listed in the relevant statute are de facto barred from recovering damages for their anxiety. Consequently, for some asbestos workers the level of proof is extremely low, while for others it is unattainably high. This distinction regarding levels of proof of anxiety as between different categories of asbestos workers is unfair and

76 Cass soc, 3 March 2015, no ${ }^{\circ} 13-20.474$ and joined cases (to be published).

77 Cass soc, 3 March 2015, no¹3-26.175 (to be published): ‘Qu'en statuant ainsi, alors que la réparation du préjudice d'anxiété n'est admise, pour les salariés exposés à l'amiante, qu'au profit de ceux remplissant les conditions prévues par l'article 41 de la loi du 23 décembre 1998 et l'arrêté ministériel, la cour d'appel a violé les textes susvisés.'

78 See fn 75.

79 See M Keim-Bagot, Préjudice d'anxiété: la Cour de cassation referme la boîte de Pandore, Droit social 2015, 360; $J$ Knetsch, Les limites de la réparation du préjudice d'anxiété, D 2015, no ${ }^{\circ} 16$ (30.04.2015) 968.

80 Cass soc, 3 March 2015, no 13-21.832 and joined appeals (to be published): 'Attendu que le salarié, qui a travaillé dans l'un des établissements mentionnés à l'article 41 de la loi n 98-1194 du 23 décembre 1998 et figurant sur une liste établie par arrêté ministériel pendant une période où y étaient fabriqués ou traités l'amiante ou des matériaux contenant de l'amiante, et se trouve, par le fait de l'employeur, dans une situation d'inquiétude permanente face au risque de déclaration à tout moment d'une maladie liée à l'amiante, qu'il se soumette ou non à des contrôles et examens médicaux réguliers, subit un préjudice spécifique d'anxiété.' 
discriminatory, and can only be explained (though not justified) by the judges' desire to guard against a rise in claims.

The proposed requirement of a proven condition of anxiety offers a potential solution to this problem. Instead of distinguishing between different categories of asbestos workers, it would have been wiser for the Cour de cassation to make compensation dependent on the satisfaction of two conditions. Firstly, the workers should prove that they have been exposed to asbestos by their employers because of the latters' failure to take precautionary measures to prevent such exposure. Secondly, the workers should provide proof of their anxiety and not merely allege its existence. As it is a legal fact (fait juridique as opposed to acte juridique), the claimant can use any form of evidence for these purposes.

\section{The requirement of a recognised psychiatric illness in English law: an excessively stringent level of proof}

In contrast to the French cases, the English case of Grieves $v$ FT Everard \& Sons Ltd shows that the safeguards relating to the scope of liability still remain. Mr Grieves was treated differently because, unlike the other employees, he sustained a diagnosed clinical depression due to his knowledge of pleural plaques in his system. The requirement of proof of a clinically diagnosed psychiatric illness appears harsh on claimants, but there are a variety of reasons why this rule is applied. ${ }^{81}$ Primarily, it is guided by public policy and in particular by the fear of an uncontrollable flood of claims. Additionally, evidence of a mental condition falling below a recognised psychiatric illness is thought to be more easily fabricated since no agreed diagnostic criteria of anxiety are available. For both these reasons, the requirement of a recognised psychiatric illness was said to be 'a powerful control mechanism' by Morland $\mathrm{J}$ in the CJD litigation. ${ }^{82}$ However a successful action in negligence does not solely rely on the existence of damage. It requires a duty of care to be owed, a breach of that duty and a causal link between the breach of duty and the damage. These requirements constitute further control mechanisms which can also be used to limit the scope of liability. Therefore, there is a need to determine whether these control mechanisms would be able to prevent undeserving claims from being brought to court if the threshold of

81 Mulheron, Rewriting the Requirement for a 'Recognized Psychiatric Injury' in Negligence Claims (2012) 32 Oxford Journal of Legal Studies (OJLS) 77, 81-84.

82 Group B Plaintiffs v Medical Research Council [1997] 41 BMLR 157 (QB), [162]: 'The requirement in England that a plaintiff must prove a genuine psychiatric injury is a powerful control mechanism'. 
damage were to be lowered from a diagnosed psychiatric illness to anxiety of a degree that impacts on the claimant's way of life. In order to determine whether substantial anxiety of this nature could be a suitable threshold of damage in cases of fear of future illness only, ${ }^{83}$ two main control mechanisms will be studied: the test of reasonable foreseeability (a) and causation (b).

\section{a The test of reasonable foreseeability}

As has been mentioned previously, the claimant needs to show that he is owed a duty of care by the defendant to stand a chance of being successful. However, in fear of future illness cases there may well be an established duty of care (employer/employee, doctor/patient). As a consequence the claimant will not need to demonstrate that he is in a close legal relationship with the defendant or that the recognition of a duty of care is fair, just and reasonable: ${ }^{84}$ it is assumed that these general requirements are satisfied. In practice, the claimant will only have to show that the defendant should have reasonably foreseen that his negligent action could result in psychiatric harm.

However the test of reasonable foreseeability is not as easy to satisfy as might appear at first. The claimant generally has to establish that the defendant should have foreseen psychiatric harm. ${ }^{85}$ This objective test has been designed to prevent persons who are particularly susceptible to psychiatric harm from being able to succeed in a claim. The claimant will pass this test only if he can establish that a 'normal' person would also suffer from psychiatric harm when put in the same circumstances. In other words, it does not matter whether psychiatric harm is foreseeable in the particular individual. If one were to admit substantial anxiety as an appropriate standard of damage, adoption of this test would still provide a formidable control mechanism in fear of future illness claims. The claimant would pass the test only if he can establish that the defendant should have foreseen substantial anxiety in a person of ordinary fortitude. The application of this test would still prevent claimants who are particularly vulnerable to anxiety from recovering damages.

83 This paper does not seek to advocate a lower threshold of damage in all cases of psychiatric harm but only in the specific context of the fear of future illness. This opinion is mainly justified not only because the future illness which is feared is generally very serious, if not life-threatening, but also because people usually have to live with this fear for many years, if not decades. As such, the length of time with which these people have to live with their anxiety can provide a justification for a lower threshold of damage.

84 Applying the principles laid down in Caparo v Dickman [1990] UKHL 2.

85 Bourhillv Young [1943] AC 92. 
Those opposed to the recognition of anxiety as damage in fear of future illness cases could still argue that, in the context of the employer's established duty of care to employees, the principles of the 'stress-at-work' cases apply. This was accepted in the Grieves case. The 'stress-at-work' principle establishes that the threshold question is to know whether this kind of harm to this particular employee was reasonably foreseeable. ${ }^{86}$ This means that the claimant has to prove either that the employer knew or should have known of his particular vulnerability to stress or, if the claimant cannot do $\mathrm{so}^{87}$ that the employer should have foreseen that the creation of the risk of future illness would cause psychiatric harm to a person of reasonable fortitude. This is the same threshold as discussed in the previous paragraph and as such, if the threshold of damage was lowered to substantial anxiety, the same safeguard would also apply. Moreover, in such cases employees generally develop mental harm - whether anxiety or a genuine psychiatric illness - only after having been informed of the risk of contracting disease in future. However, knowledge of this risk usually comes a long time after being exposed to it. In such circumstances, it seems unlikely that the judge will admit that the employer should have foreseen at the time of exposure that this might result in substantial anxiety ten, twenty, or thirty years later in a person of ordinary fortitude.

For these reasons, a lower threshold of damage in the context of the fear of future illness should not produce a rise in the number of claims. The test of reasonable foreseeability, as already applied by the courts, constitutes a powerful control mechanism to limit the scope of liability if needed.

\section{b Causation}

The claimant must also be able to demonstrate that, but for the breach of duty, he would not have suffered psychiatric harm. This is the test for causation which has to be proved on a balance of probabilities. Although it may seem straightforward, the CJD litigation and the asbestos case show the contrary. In these cases, it was argued that the negligence per se did not actually cause the damage. Rather, it was the knowledge of a risk of physical injury which led to the development of the psychiatric harm. This knowledge, however, was gained a significant period of time after the breach of duty. The judges consequently considered that there was no causal link between the breach of duty and the damage. In the context of

86 Hatton $v$ Sutherland [2002] EWCA Civ 76 (CA), [23].

87 Only in exceptional cases will the claimants be able to prove that the employer should have known their particular vulnerability to anxiety. 
health-related risk, proving causation may be challenging for claimants since the knowledge of such risks may come years after the negligence. The situation will probably be the same if substantial anxiety were to be accepted as an appropriate threshold. Claimants would mostly develop anxiety only when they learn of the risk of contracting a disease, which could be a long time after the breach of duty. The courts could therefore still rely on the absence of proof of causation to reject their claims of anxiety. Causation thus also proves to be a powerful control mechanism, enabling the courts to prevent undeserving claims from being successful.

It appears then that the supposed justifications for a requirement of a recognised psychiatric illness as an appropriate threshold of damage are devoid of substance since other existing control mechanisms already provide similar safeguards. As a result, the requirement of a genuine psychiatric illness appears to make the claimant's burden of proof unnecessarily difficult to discharge. Nevertheless a system like the French where the existence of anxiety can be inferred from other facts probably sets the standard of proof too low and should not be applied in this context. The absence of clear conditions guiding the use of the specific head of damage for anxiety in French law cannot be combined with a low level of proof. To do so would create legal uncertainty and open the door to a potentially large number of claims. In conclusion, the comparison of French and English law reveals that the level of proof remains largely unsatisfactory in each jurisdiction - too low in France and too stringent in England. Consequently, it is proposed here that claims in relation to the fear of future illness should only be successful if the alleged anxiety is actually proved, though there should be no requirement that a psychiatric illness has been diagnosed. The means by which anxiety should be proved can be debated further but that goes beyond the scope of this paper.

\section{Conclusion}

The foregoing comparison of French and English law shows that compensation for the fear of future illness remains open to considerable debate, both in principle and regarding the conditions under which damages may be available.

When the fear of future illness coexists with an actual physical injury, both legal systems provide for compensation and award damages for this anxiety. In such circumstances, the fear of future illness has to be regarded as a consequence of the physical injury. The 'single action rule', referred to previously, undoubtedly provides a substantive explanation of the practice. However, another reason might justify this position taken too: the anxiety alleged by the claimants prob- 
ably appears more substantial, more reasonable and maybe even more foreseeable if the person suffers from a physical injury. Thus the existence of physical damage probably contributes to the substantiating of a claim for anxiety.

The problem arises when the claim for anxiety stands on its own. English courts have proved very rigid on this matter and have systematically rejected claims in connection with mere anxiety. The threshold required by English law is very stringent: a genuine psychiatric illness has to be diagnosed for the claimant's condition to be legally actionable. The burden of proof on the claimant is high since it is not enough that the defendant negligently put the claimant at risk of contracting a disease unless an actual psychiatric condition is diagnosed. Some cases have nevertheless shown a more flexible approach but the requirement of a psychiatric injury was still maintained. In any case, these decisions constitute an exception to the normally prevailing approach and the outcomes reached are specific to their particular facts. As such it is very unlikely that they will serve as precedents for future claims. However, the reasons put forward to justify this rigorous approach seem largely overstated when one has regard to the existence of other control mechanisms that would prevent most of the feared consequences from arising.

French courts have on the contrary been a lot more flexible than their English counterparts and have recognised anxiety as a specific head of damage. This flexibility is mainly due to the lack of proper control mechanisms in the use of this new category, which gives rise to its own difficulties. Some claims of anxiety have been successful even though the potential existence of the risk of contracting a disease was still in question. The few courts that have welcomed these claims have arguably been driven by the goal of prevention of potential physical harm. Nevertheless, this approach if generalised would threaten not only the traditional functions of the law of tort but also the conditions under which liability is generally recognised. These conditions constitute safeguards which aim to prevent unsubstantiated claims from being successful. As such, the generalised distortion of the conditions of liability would endanger the whole system of tort law. The most recent decisions of the Cour de cassation suggest that France's Supreme Court judges are now taking a more rigorous approach. However, their refusal to address matters of general principle has led to the perpetuation of anomalies. Some asbestos workers can obtain damages without having to prove their anxiety while others are denied any recovery for their anxiety without being allowed the chance to substantiate their claim. This discriminatory distinction could be avoided if the Cour de cassation were to determine general conditions under which anxiety as a specific head of damage can be compensated.

In the light of what has been said above, it seems imperative to identify proper boundaries to apply in fear of future illness claims. The propositions 
presented in the previous section of this article are a first step in that direction, presenting a middle way between the extremes of approach to be found in current English and French law, whose inadequacies were demonstrated in earlier sections of the paper. However, it is clear that additional reflection is required in order to avoid further legal uncertainty in this area. 